\title{
Rhizobacterial salicylate production provokes headaches!
}

\author{
Peter A. H. M. Bakker • LongXian Ran • \\ Jesús Mercado-Blanco
}

Received: 20 January 2014 / Accepted: 25 March 2014 / Published online: 12 April 2014

(C) Springer International Publishing Switzerland 2014

\begin{abstract}
Background Salicylic acid (SA) is produced in significant amounts by certain plant growth promoting rhizosphere bacteria, and some of these rhizobacteria have the ability to induce systemic resistance against diseases in plants. Exogenous application of SA to plants has long been known to lead to protection against a range of plant pathogens through the elicitation of systemic acquired resistance. Thus, it is reasonable to assume that the SA producing plant beneficial rhizobacteria elicit induced resistance through the production of SA.

Scope and conclusions However, we discuss here that bacterial secretion of SA in vitro appears to be an artifact and that the bacteria will normally incorporate SA into SA-containing metabolites, mainly SA-based siderophores, under environmental conditions. Therefore, we argue that rhizobacteria do not likely
\end{abstract}

Responsible Editor: Philippe Hinsinger.

\section{P. A. H. M. Bakker $(\square)$}

Plant-Microbe Interactions, Department of Biology, Utrecht University, Padualaan 8, $3584 \mathrm{CH}$ Utrecht, The Netherlands e-mail: P.A.H.M.bakker@uu.nl

L. Ran

College of Forestry, Agricultural University of Hebei, Baoding 071001 Hebei, People's Republic of China e-mail: longxianran@163.com

J. Mercado-Blanco

Departamento de Protección de Cultivos, Instituto de agricultura Sostenible (CSIC), Apartado 4084,

14080 Córdoba, Spain

e-mail: jesus.mercado@ias.csic.es excrete free SA into the rhizosphere thereby not inducing resistance in plants through this metabolite. SA detected in the rhizosphere is most likely produced by the plant and we discuss the impact of this phenolic compound on microbial interactions.

Keywords Antibiotic resistance - Induced systemic resistance - Microbial interactions · Pseudomonas spp. Rhizosphere $\cdot$ Salicylate $\cdot$ Siderophores

\section{Salicylic acid, a versatile molecule}

Each year approximately $40,000 \mathrm{t}$ of aspirin, the acetylated form of the phenolic compound salicylic acid (SA), is produced (Fuster and Sweeny 2011). Acetylsalicylic acid is the most widely used drug worldwide. The history of SA as a cure for aches and fevers goes back thousands of years (Jack 1997). Around 4000 BC the Assyrians used extracts of willow leaves to combat joint pain (Mahdi 2010). The bark of willow contains relatively large quantities of SA. Beavers consume willow bark and the secretion from the castor sac, the SA-containing castoreum, was prescribed for many maladies until the 1700s (Müller-Schwarze and Sun 2003). In animal cells, anti-inflammatory properties of aspirin and SA are partly mediated by inhibition of IKB kinase- $\beta$ activity (Yin et al. 1998). Aspirin also appears to prevent recurrent cardiovascular events and to reduce incidence of colorectal cancer; however, the underlying mechanisms need further investigations (Fuster and Sweeny 2011). 
In plants SA plays a crucial role in responses to pathogen attack (Vlot et al. 2009), but also has a role in responses to abiotic stresses and in growth and development (Rivas-San Vicente and Plasencia 2011). The recently published book edited by Hayat et al. (2013) offers an extensive overview of current knowledge on SA and plant growth and development. The presence of SA in plants is well documented and for some plant species levels in excess of $1 \mu \mathrm{g}$ per gram fresh weight have been reported (Raskin 1992). SA is required as a signaling molecule in systemic acquired resistance (SAR) that develops in plants after attack by pathogens that cause necrosis (Durrant and Dong 2004). SAR is effective against a broad range of pathogens and the protection can be long-lasting. Manipulation of this induced defense mechanism thus has potential for plant protection. Exogenous application of SA or SA mimics can indeed protect plants against a range of pathogens (Oostendorp et al. 2001). Whereas animals and plants both respond to application of SA, effects on fungi have hardly been studied. In the white button mushroom Agaricus bisporus application of SA did not result in protection against the fungal pathogen Lecanicillium fungicola (Berendsen et al. 2013), suggesting that SA inducible defense pathways are lacking or ineffective.

Production of SA by bacteria has been reported frequently, in many cases related to the production of siderophores under iron limited conditions. Next to playing a role in iron acquisition the effects of SA on plants suggest that the production of this metabolite by bacteria can have a significant impact on plant-microbe interactions in the rhizosphere. However, as yet there is no convincing evidence for such a role of SA. Here we review both the genetics and the influence of physiological conditions on SA biosynthesis in bacteria. Postulated implications of bacterial SA production in induced disease resistance and impact of SA on bacterial ecology are discussed in detail.

\section{Genetics of SA biosynthesis in bacteria}

Biosynthesis of SA (2-hydroxybenzoic acid) may proceed either from the phenylpropanoid or the chorismate/ isochorismate pathways. In plants, SA can be synthesized from any of these two major enzymatic routes (Lee et al. 1995; Verberne et al. 1999; Wildermuth et al. 2001; Garcion and Métraux 2006; Wildermuth 2006; Chen et al. 2009; Vlot et al. 2009; Dempsey et al. 2011). In
SA-producing bacteria, however, the chorismate/ isochorismate route is the unique biosynthetic pathway so far identified (Kerbarh et al. 2005).

Production of SA by bacteria is linked to their growth under iron-limiting conditions. SA has been suggested to act as an endogenous siderophore under iron limitation in Mycobacterium spp. (Ratledge and Winder 1962), Pseudomonas spp. (Ankenbauer and Cox 1988; Anthoni et al. 1995; Meyer et al. 1992; Visca et al. 1993), Azospirillum lipoferum (Saxena et al. 1986), and Pseudomonas cepacia (Sokol et al. 1992). However, the role of SA as a siderophore per se was questioned by Chipperfield and Ratledge (2000) who suggested that $\mathrm{SA}$ cannot bind $\mathrm{Fe}^{3+}$ at $\mathrm{pH}$ above 6 .

In general synthesis of SA in bacteria is concomitant to the biosynthesis of SA-based siderophores. SA is an essential precursor or intermediate in the synthesis of the bacterial siderophores mycobactin T in Mycobacterium tuberculosis (Snow 1965), mycobactin S in Mycobacterium smegmatis (Hudson and Bentley 1970; Ratledge and Hall 1972), parabactin in Paracoccus denitrificans (Person and Neilands 1979), pyochelin in Pseudomonas aeruginosa (Cox et al. 1981; Ankenbauer and Cox 1988; Brandel et al. 2012), Pseudomonas fluorescens (Castignetti 1997), Burkholderia arboris (Le Dang et al. 2011) and Burkholderia cenocepacia (Farmer and Thomas 2004), maduraferrin in Acinomadura madurae (Keller-Schierlein et al. 1988), vulnibactin in Vibrio vulnificus (Okujo et al. 1994), aeruginoic acid in P. fluorescens (Carmi et al. 1994), pseudomonine (Psm) in P. fluorescens (Anthoni et al. 1995; Mercado-Blanco et al. 2001) and Pseudomonas entomophila (Matthijs et al. 2009), and yersiniabactin in Yersinia spp. (Drechsel et al. 1995; Chambers et al. 1996; Pelludat et al. 2003; Bultreys et al. 2006) and Pseudomonas syringae pv. tomato (Jones et al. 2007). Therefore, genetics and regulation of SA biosynthesis must be analyzed along with the machinery leading to siderophores having SA as an essential moiety.

The evidence that bacterially-produced SA proceeds via the shikimate pathway came from the pioneering work of Ratledge (1969). In his experiments, high level of $\left[{ }^{14} \mathrm{C}_{7}\right]$-shikimic acid was incorporated into $\mathrm{SA}$ in M. smegmatis, both alone and in the presence of unlabeled co-substrates (i.e. L-phenylalanine, L-tyrosine, $p$ aminobenzoic, etc.). Hudson and Bentley (1970) later demonstrated that all seven carbon atoms of shikimic acid are incorporated into SA upon feeding cultures of M. smegmatis with labelled shikimic acid. Then, 
Marshall and Ratledge (1971) showed that cell extracts of this bacterium were able to convert chorismic acid to isochorismic acid and subsequently to SA. Thus, synthesis of SA took place only with isochorismic acid as substrate, and $\mathrm{NAD}^{+}$was not required. Finally, Marshall and Ratledge (1972) proposed that SA is synthesized from chorismic acid with isochorismate as the only intermediate, shikimic acid being the precursor of the former. This route was verified not only in M. smegmatis, but also in M. tuberculosis and Mycobacterium fortuitum, and the trivial name of salicylate synthase was suggested for the final enzyme of the pathway (Marshall and Ratledge 1972).

The genetic basis of salicylate biosynthesis in bacteria via the chorismate/isochorismate pathway was first established for $P$. aeruginosa PAO1 by Serino et al. (1995). SA is a precursor of the siderophore pyochelin in strain PAO1 (Ankenbauer and Cox 1988). Two adjacent genes involved in SA synthesis were cloned and sequenced: $p c h B$ (coding for salicylate synthase) and $p c h A$ (coding for an isochorismate synthase, ICS) (Gaille et al. 2003). Expression of the $p c h B$ gene in an $E$. coli ent $B$ (coding for isochorismatase) mutant resulted in SA production. In addition, when an $E$. coli entC (ICS) mutant was transformed with $p c h B A$ genes from strain PAO1, it became an SA producer (Serino et al. 1995). The pchB product is an isochorismate pyruvate lyase (IPL), proposed to also act as a functional chorismate mutase (Gaille et al. 2002), a suggestion confirmed by Künzler et al. (2005). While SA synthesis by strain PAO1 occurs in a two-step reaction, other SAproducing bacteria harbour the genetic/enzymatic machinery for the direct conversion of chorismate to salicylate. Thus, MbtI of M. tuberculosis (Harrison et al. 2006), YbtS of Yersinia pestis (Gehring et al. 1998), or Irp9 of Yersinia enterocolitica (Pelludat et al. 2003; Kerbarh et al. 2005) are true salicylate synthases, capable of ring isomerization and pyruvate lyase activities in a single enzyme, converting chorismate directly into SA (Pelludat et al. 2003). These proteins are smaller than PchA and bacteria harbouring them do not have $p c h B$ homologs nearby ICS-coding genes (Gehring et al. 1998; Quadri et al. 1998).

The two-enzyme process characterized for P. aeruginosa (Serino et al. 1995; Gaille et al. 2003) has been confirmed for other pseudomonads. The first step, chorismate to isochorismate, catalysed by an ICS is encoded by $p m s C$ in $P$. fluorescens WCS374 (MercadoBlanco et al. 2001) and P. entomophila L48 (Matthijs et al. 2009), both homologous to the product of $p \operatorname{ch} A$ in $P$. aeruginosa PAO1. The second step, conversion of isochorismate to SA, is catalysed by an IPL (Sattely and Walsh 2008; Wuest et al. 2009) encoded by pmsB in strains WCS374 (Mercado-Blanco et al. 2001) and L48 (Matthijs et al. 2009) and homologous to $p c h B$ in strain PAO1. Similar to the pyochelin and SA biosynthetic gene cluster in $P$. aeruginosa PAO1 (Serino et al. 1995, 1997), pmsB and pmsC of strains WCS374 and L48 are part of the operon pmsCEAB involved in the biosynthesis of SA and the siderophore Psm (MercadoBlanco et al. 2001; Matthijs et al. 2009). Heterologous expression of $p m s B$ and $p m s C$ was accomplished in Pseudomonas putida and Escherichia coli cells. Deletions affecting $p m s C$ reduced SA production in E. coli, whereas deletion of $p m s B$ enterely abolished it (Mercado-Blanco et al. 2001). Final evidence of the involvement of $p m s B$ as the key gene for SA biosynthesis in strain WCS374 came after marker-exchange mutant analysis (Djavaheri et al. 2012). Remarkably, the Psm biosynthesis gene cluster as well as genes putatively involved in the transport of this siderophore have identical organization in P. fluorescens WCS374, a rhizosphere biocontrol strain (Djavaheri et al. 2012), and P. entomophila L48, an entomopathogenic bacterium (Matthijs et al. 2009). Recently, the gene cluster for the biosynthesis and uptake of Psm (or a Psm-like compound) has been reported to be present in the genomes of the biocontrol strains Pseudomonas spp. BG33R and P. fluorescens A506. However, whether this secondary siderophore is biosynthesized by these strains has yet to be confirmed (Loper et al. 2012).

\section{Environmental and physiological factors influencing bacterial SA biosynthesis}

As already mentioned, bacterial SA biosynthesis is linked to the assembly line of SA-based siderophores. Considering that siderophores are produced to cope with $\mathrm{Fe}^{3+}$ limiting conditions, the major factor influencing biosynthesis of SA and SA-based siderophores is $\mathrm{Fe}^{3+}$ availability (Ratledge and Winder 1962; Cox and Graham 1979). Indeed, SA concentration increases when available iron in the medium is low (Ratledge and Hall 1971; Leeman et al. 1996).

The promoter of the $p c h D C B A$ operon, involved in the biosynthesis of SA and pyochelin in P. aeruginosa PAO1 (Serino et al. 1995, 1997), is positively controlled 
by the PchR protein in the presence of pyochelin (Reimmann et al. 1998) and negatively by the Fur (Ferric Uptake Regulation) repressor (Bagg and Neilands 1987; de Lorenzo et al. 1987) in the presence of iron (Serino et al. 1997). Iron availability, and pyochelin acting as an autoinducer, are major signals determining the yield of the pyochelin pathway by regulating the expression of the pchA (ICS) gene (Gaille et al. 2003). The PchA concentration was proposed as an important factor influencing this siderophore biosynthetic pathway: pyochelin acting as a positive signal and iron as the negative one (Gaille et al. 2003). Whether this scenario can also be portrayed for other SA-based siderophores such as Psm is not known. Nevertheless, presence of two potential Fur boxes in the promoter region of the pmsCEAB operon as well as repression of this gene cluster by iron has been confirmed (Mercado-Blanco et al. 2001). Availability of iron and diverse substrates, as well as temperature affect bacterial production of SA and SA-based siderophores (Leeman et al. 1996; De Meyer and Höfte 1997; Press et al. 1997; Audenaert et al. 2002; Ran et al. 2005a; Djavaheri et al. 2012). Despite that production of SA by bacteria can be easily confirmed in vitro, SA synthesis in vivo, in the ecological niche where they naturally live or can be artificially introduced, is more difficult to assess. For instance, while production of SA by strain 7NSK2 is measurable in vitro (De Meyer and Höfte 1997), production in vivo (tomato roots) could not be demonstrated (Audenaert et al. 2002). This could be due to the detection limit of the methodological approach used or to the possibility that SA could be entirely channeled to pyochelin synthesis when bacteria are grown in a natural environment. Indeed, these authors have demonstrated that when strain 7NSK2 is grown in the presence of L-cysteine, production of pyochelin, composed of one molecule of SA and two molecules of cysteine, is enhanced (Cox et al. 1981). Since cysteine is a component of plant roots exudates, including tomato (Solanum lycopersicum Mill.) (Gamliel and Katan 1992), it is plausible to assume that SA is incorporated into pyochelin in the tomato rhizosphere (Audenaert et al. 2002). This could also operate for P. fluorescens WCS374, which produces relatively high amounts of SA in vitro (see below) (Leeman et al. 1996; Mercado-Blanco et al. 2001; Ran et al. 2005a; Djavaheri et al. 2012). However, in standard succinate medium (SSM) (Meyer and Abdallah 1978), that is typically used for SA determination, L-histidine and L- threonine, the other two building blocks required for Psm biosynthesis (Mercado-Blanco et al. 2001; Sattely and Walsh 2008; Djavaheri et al. 2012) are lacking. Thus similar to the situation for strain 7NSK2, SA production by WCS374 in the rhizosphere may be strongly reduced, or completely abolished, due to the presence of histidine and threonine in the root exudates. Excretion of SA has also been reported in M. smegmatis as an early metabolic event which is then followed by a re-absorption by the cells to be incorporated into the mycobactin biosynthetic route (Hudson and Bentley 1970; Marshall and Ratledge 1972).

Production of SA is also influenced by temperature. Ran et al. (2005a) reported that the relatively high production of SA in vitro by strain WCS374 is even enhanced at supra-optimal temperatures (i.e. $31-33^{\circ} \mathrm{C}$ ). This increase was also observed for $P$. fluorescens CHA0r, but not for P. fluorescens WCS417r or P. aeruginosa 7NSK2 (Ran et al. 2005a).

Production of SA by rhizosphere bacteria in situ is difficult to confirm. So is the unravelling of its potential function(s) in a dynamic environment where multiple trophic interactions take place which, in addition, are influenced by diverse physicochemical factors. SA is produced at iron limiting conditions, a situation commonly found in the rhizosphere (Loper and Henkels 1997; Duijff et al. 1999). While this primary condition induces SA biosynthesis, its functioning as a true siderophore would only be expected at the specific situation of $\mathrm{pH}<6$ (Chipperfield and Ratledge 2000). Considering that $\mathrm{pH}$ in the rhizosphere may rapidly change due to diverse factors (Hinsinger et al. 2003), bacterial SA working as a siderophore in the rhizosphere or in the root interior seems to be a highly-conditioned event. Moreover, presence of root exudates at specific rhizosphere spots would provide important substrates to bacteria needed for siderophore biosynthesis, thus favouring the channeling of free SA towards SA-based siderophore assembly. On the other hand, some bacteria can overproduce SA at high temperatures, pointing to scenarios (i.e. high soil temperature during hot summers and/or tropical areas) where biosynthesis of SA and specific SA-based siderophores could be enhanced, triggering responses in plants which otherwise would remain silent under low-temperature conditions. Finally, SA may pose ecological advantages to SA-producing bacteria, due to its antibacterial and antifungal properties (Gershon and Parmegiani 1962; Himejina and Kubo 1991). Whereas the potential of SA as an antibiotic in 
the rhizosphere has hardly been investigated, production of a salicylate containing antibiotic, promysalin, by P. putida RW10S1 has been described (Li et al. 2011).

Changes in the production of SA and SA-based siderophores will largely depend on the dominating environmental factors at any given moment. In fact, the same SA-based siderophore can be produced under different trophic scenarios, for instance by saprophytic (i.e. mycobactin in M. smegmatis or Psm in P. fluorescens AH2) (Anthoni et al. 1995; Adilakshmi et al. 2000), entomopathogenic (Psm in P. entomophila L48) (Matthijs et al. 2009), opportunistic pathogenic (i.e. vulnibactin in $V$. vulnificus or pyochelin in P. aeruginosa) (Okujo et al. 1994; Serino et al. 1997), animal pathogenic (i.e. mycobactin in M. tuberculosis or yersiniabactin in Y. enterocolitica) (Pelludat et al. 2003; Harrison et al. 2006), plant pathogenic (i.e. yersiniabactin in P. syringae pv. tomato DC3000) (Jones et al. 2007), or plant beneficial (i.e. Psm in P. fluorescens WCS374) (Mercado-Blanco et al. 2001) bacteria. In pseudomonads, the production of SAcontaining siderophores may be an adaptation to environmental conditions under which the production of their fluorescent siderophore pyoverdine is shut down, for example high temperatures.

\section{SA production by plant growth promoting rhizobacteria}

Plant growth-promoting rhizobacteria (PGPR) are rootcolonizing bacteria that exert beneficial effects on plant growth (Bakker et al. 2007b). Several PGPR strains have been reported to have the ability to produce SA (Table 1). Here we summarize well documented examples of SA production by PGPR.

Pseudomonas is the best studied genus for SA production and SA-producing species include P. aeruginosa, Pseudomonas aureofaciens, Pseudomonas corrugata and P. fluorescens (Table 1). P. fluorescens holds the largest number of SA-producers studied, including strains WCS374 and WCS417 (Geels and Schippers 1983; Lamers et al. 1988), CHA0 (Stutz et al. 1986), Pf4-92, Pf12-94, Pf151-94 and Pf179-94 (Saikia et al. 2003, 2005), or PICF3, PICF4 and PICF7 (Mercado-Blanco et al. 2004). The latter strains were reported to produce only minor amounts of SA when grown in SSM (Mercado-Blanco et al. 2004). Among them, the olive (Olea europaea L.) root endophytic strain PICF7 (Prieto and Mercado-Blanco 2008) has been shown to be an efficient biological control agent (BCA) against Verticillium wilt of olive (Verticillium dahliae) (López-Escudero and Mercado-Blanco 2011; Prieto et al. 2009), and able to trigger a broad range of defense responses in olive root tissues (Schilirò et al. 2012).

P. fluorescens strains WCS374 and WCS417, isolated from respectively potato (Solanum tuberosum L.) and wheat (Triticum aestivum L.) rhizospheres, have been investigated for plant growth promotion and biocontrol activities in several plant species and against diverse pathogens (Bakker et al. 2007a; De Vleesschauwer and Höfte 2009; Van Loon and Bakker 2005). In vitro production of SA by strains WCS374 and WCS417 was measured in SSM with low iron availability. Strain WCS374 can be considered as a SA 'super-producer' (up to $55 \mu \mathrm{g}$ per $\mathrm{ml}$ ) in vitro. This amount is approximately 10 times higher than that detected for WCS417 as well as for other SA producers under similar culturing conditions (Leeman et al. 1996; Mercado-Blanco et al. 2001; Ran et al. 2005a).

P. fluorescens CHA0, a well-studied PGPR strain, was originally isolated from roots of tobacco (Nicotiana tabacum L.) plants grown in soil naturally suppressive to black root rot, a disease caused by Thielaviopsis basicola (Stutz et al. 1986). For this strain in vitro SA production was detected under low iron conditions (Reimmann et al. 1997), and effects of carbon sources and minerals on production have been investigated (Duffy and Défago 1999). At elevated temperature, SA production by CHA0 is enhanced (Ran et al. 2005a).

Besides SA-producing rhizosphere pseudomonads, other bacterial genera have been demonstrated to produce SA. Achromobacter sp. SF2 and Bacillus spp. SF3 and SF4, originating from sunflower (Helianthus annuus L.) roots, can enhance growth of sunflower seedlings under water stress. Moreover, these bacteria produced SA and, interestingly, for all three strains SA production was significantly increased under water stress (Forchetti et al. 2010). Serratia marcescens strain 90-166 was also characterized as an SA-producing rhizobacterium (Press et al. 1997). SA biosynthesis by strain $90-166$ is affected by the culture medium with the highest production in Kings medium B that has low iron availability (Zhang et al. 2002).

Whereas measuring bacterial SA production in vitro is rather straightforward, detection of bacterial SA in the 
Table 1 SA producing plant growth-promoting rhizobacteria strains

\begin{tabular}{|c|c|c|c|}
\hline Strain & Origin & Target pathogens & $\begin{array}{l}\text { Reference for SA production } \\
\text { by the strain }\end{array}$ \\
\hline Achromobacter xylosoxidans SF2 & Sunflower soil & $\begin{array}{l}\text { Alternaria } \text { sp., Sclerotinia sp., } \\
\text { Verticillum } \mathrm{sp.}\end{array}$ & Forchetti et al. (2010) \\
\hline Bacillus pumilus SF3, SF4 & Sunflower soil & $\begin{array}{l}\text { Alternaria } \text { sp., Sclerotinia sp., } \\
\text { Verticillum sp. }\end{array}$ & Forchetti et al. (2010) \\
\hline Citrobacter & Tomato roots & Fusarium oxysporum f. sp. lycopersici & Nandhini et al. (2012) \\
\hline Klebsiella TEK 1 & Tomato leaves & F. oxysporum f. sp. lycopersici & Nandhini et al. (2012) \\
\hline Pseudomonas aeruginosa 7NSK2 & Barley roots & $\begin{array}{l}\text { Botrytis cinerea } \\
\text { Pythium splendens }\end{array}$ & $\begin{array}{l}\text { De meyer and Höfte (1997) } \\
\text { Buysens et al. (1996) }\end{array}$ \\
\hline $\begin{array}{l}\text { P. aeruginosa PaRsG18, PaRsG27, } \\
\text { PaRsG28 }\end{array}$ & Rice rhizosphere soil & Rhizoctonia solani & Saikia et al. (2006) \\
\hline P. aureofaciens $63-28$ & Cucumber rhizosphere & Pythium aphanidermatum & Chen et al. (1999) \\
\hline P. corrugata 13 & Cucumber rhizosphere & P. aphanidermatum & Chen et al. (1999) \\
\hline P. fluorescens WCS374 & Potato rhizosphere & Fusarium oxysporum & $\begin{array}{l}\text { Mercado-Blanco et al. (2001) } \\
\text { Leeman et al. (1996) }\end{array}$ \\
\hline P. fluorescens WCS417 & Wheat rhizosphere & $\begin{array}{l}\text { F. oxysporum } \\
\text { Pseudomonas syringae } \\
\text { Ralstonia solanacearum }\end{array}$ & $\begin{array}{l}\text { Leeman et al. (1996) } \\
\text { Van Wees et al. (1997) } \\
\text { Ran et al. (2005c) }\end{array}$ \\
\hline P. fluorescens CHA0 & Tobacco rhizosphere & $\begin{array}{l}\text { tobacco necrosis virus; Thielaviopsis } \\
\quad \text { basicola }\end{array}$ & $\begin{array}{l}\text { Maurhofer et al. (1994) } \\
\text { Stutz et al. (1986) }\end{array}$ \\
\hline $\begin{array}{l}\text { P. fluorescens PICF3, PICF4, and } \\
\text { PICF7 }\end{array}$ & Olive root & Verticillium dahliae & Mercado-Blanco et al. (2004) \\
\hline $\begin{array}{l}\text { P. fluorescens Pf4-92, Pf12-94, } \\
\text { Pf151-94 and Pf179-94 }\end{array}$ & Chickpea rhizosphere soil & F. oxysporum f. sp. ciceri & Saikia et al. $(2003,2005)$ \\
\hline Serratia marcescens 90-166 & Cucumber rhizozphere & $\begin{array}{l}\text { Colletotrichum orbiculare } \\
\text { Pseudomonas syringae pv. tabaci }\end{array}$ & Press et al. (1997) \\
\hline
\end{tabular}

rhizosphere is challenging. On cucumber roots colonized by $P$. aureofaciens $63-28$ or $P$. corrugata 13 , Chen et al. (1999) measured elevated levels of SA as compared to control roots. However, the elevated levels were magnitudes higher than those produced by the bacteria in vitro, and the authors concluded that the bacteria stimulated the plant itself to accumulate SA (Chen et al. 1999). For the SA and pyochelin, a siderophore containing a SA moiety, producing P. aeruginosa strain 7NSK2 (Buysens et al. 1996; De Meyer and Höfte 1997), elevated levels of SA on tomato roots colonized by the wild type strain could not be detected (Audenaert et al. 2002), suggesting that the bacteria do not produce SA in the rhizosphere. However, a mutant of 7NSK2 that cannot produce pyochelin but that does produce SA, appeared to produce significant amounts of SA in the rhizosphere (Audenaert et al. 2002).

In summary, many PGPR have the ability to produce SA in an iron availability dependent way and SA is detected on plant roots (Hayat et al. 2013), although likely originating from plant root tissues upon interaction with rhizobacteria. Given the fact that several PGPR can elicit induced systemic resistance (ISR) in plants (Van Loon et al. 1998; Kloepper et al. 2004; Bakker et al. 2003, 2007a) and that application of SA to plants leads to induced resistance against a range of pathogens (White 1979; Oostendorp et al. 2001; An and Mou 2011), attempts to study the involvement of bacterial SA in PGPR-mediated ISR are reviewed below.

\section{Are SA and SA-based siderophores involved in induced resistance?}

The involvement of SA and SA-based siderophores, i.e. Psm and pyochelin, in PGPR-mediated ISR has been studied using knock-out mutants of bacteria that no longer produce these metabolites. Another approach has been to use mutant and transgenic plants that are 
defective in the SA signaling pathway, for example $N a h G$-transformed plants that cannot accumulate SA, thereby unable to express induced resistance (Gaffney et al. 1993).

P. fluorescens WCS374 and WCS417 and P. putida WCS358 can all suppress Fusarium wilt, caused by Fusarium oxysporum f. sp. raphani (For), in radish (Raphanus sativus L.) (Leeman et al. 1996). Whereas WCS374 and WCS417 can elicit ISR in this pathosystem, $P$. putida WCS358 cannot and this strain suppresses disease by siderophore-mediated competition for iron (Leeman et al. 1996; Raaijmakers et al. 1995). Moreover, ISR by the $P$. fluorescens strains is enhanced under iron-limiting conditions, a situation favoring production of iron-regulated metabolites including SA. Since strain WCS358 (a non SA producer) does not elicit ISR in radish, Leeman et al. (1996) suggested that rhizobacteria-produced SA is essential for ISR. This suggestion was sustained by the fact that application of as low as $100 \mathrm{fg}$ of SA to radish roots induced resistance against For. However, in the model system Arabidopsis thaliana-Pseudomonas syringae pv. tomato (Pst) WCS358 can elicit ISR, so can WCS417 (a moderate SA producer), whereas WCS374 (a SA 'super producer') cannot (Van Wees et al. 1997). Moreover, ISR by WCS417 was still effective in NahG-transformed Arabidopsis plants in which exogenous application of SA does not induce resistance (Pieterse et al. 1996). These results argue against SA being involved in ISR by the SA-producing strain WCS417.

WCS374 is an intriguing fluorescent pseudomonad strain because of its ability to produce large amount of $\mathrm{SA}$ in vitro (see above). This strain can trigger ISR against Fusarium in radish (Leeman et al. 1996), and against Ralstonia solanacearum in Eucalyptus (Eucalyptus urophylla S. T. Blake) (Ran et al. 2005b), but appeared to be unable to induce resistance against Pst in A. thaliana (Ran et al. 2005a; Van Wees et al. 1997). However, when applied at low population densities, P. fluorescens WCS374r did elicit ISR in A. thaliana against the bacterial pathogen $P s t$, with no requirement of SA or siderophore production (Djavaheri et al. 2012). Also, WCS374r-mediated ISR against the fungus Magnaporthe oryzae in rice (Oryza sativa L.) does not require bacterial SA production (De Vleesschauwer et al. 2008). Overall, these results suggest that involvement of WCS374-produced SA in ISR is unlikely.

Besides SA, strain WCS374 produces the SA-based siderophore Psm under iron-limited conditions
(Djavaheri et al. 2012; Mercado-Blanco et al. 2001). A possible role of Psm in ISR in the pathosystem Eucalyptus- $R$. solanacearum was investigated using transformant JM218(pMB374-07), a pyoverdin mutant of WCS358 (Marugg et al. 1985) that is transformed with the Psm biosynthesis genes of WCS374 (MercadoBlanco et al. 2001). Reduction of bacterial wilt was not observed upon treatment with JM218(pMB374-07), discarding Psm as an ISR triggering factor in this system (Ran et al. 2005b). Moreover, the possible role of Psm in ISR was evaluated in the rice-M. oryzae pathosystem by using mutants of WCS374 deficient in Psm production (De Vleesschauwer et al. 2008). It was concluded that Psm is not essential for ISR against the leaf blast pathogen in rice (De Vleesschauwer et al. 2008). Finally, the potential involvement of Psm in ISR against Pst was also tested in Arabidopsis. The Pms mutants behaved similar to the wild type in their ability to elicit ISR against $P s t$, again suggesting that Psm production by WCS374r is not required for eliciting ISR in Arabidopsis (Djavaheri et al. 2012).

P. aeruginosa strain $7 \mathrm{NSK} 2$ can induce resistance in several plant species, including bean, rice, tobacco and tomato (De Vleesschauwer and Höfte 2009). The ability of 7NSK2 to elicit ISR appeared to be linked to SA production by the bacteria (De Meyer and Höfte 1997; De Meyer et al. 1999b), and nanogram amounts of SA produced by this strain appeared to be sufficient (De Meyer et al. 1999a). Audenaert et al. (2002) postulated that SA is not the inducing compound of 7NSK2, but ISR depends on the production of both pyochelin and pyocyanin. Apparently in the rhizosphere, 7NSK2 does not produce SA, but instead the SA is channeled into the SA-containing siderophore pyochelin (Audenaert et al. 2002). However, a mutant of 7NSK2 that cannot produce pyochelin, but that does produce SA (mutant $\mathrm{KMPCH}$ ) was demonstrated to elicit induced resistance through the production of SA (Audenaert et al. 2002).

Pseudomonas fluorescens strain CHA0 is a SA producer under iron-starvation conditions (Meyer et al. 1992) and it can induce systemic resistance against Tobacco necrosis virus (TNV) (Maurhofer et al. 1994). CHA400, a pyoverdin-negative but SA-positive mutant of CHA0, partially maintained the ability to induce resistance against TNV. Furthermore, introduction of the SA biosynthetic genes $p c h B A$ from $P$. aeruginosa PAO1 (Serino et al. 1997) into P. fluorescens strain P3, which does not produce SA, rendered this strain capable of SA production in vitro. Furthermore, SA production 
by P3 significantly improved its ability to induce systemic resistance in tobacco against TNV (Maurhofer et al. 1998).

To further understand the role of bacteriallyproduced SA, several of the above-mentioned SAproducing Pseudomonas strains, including P. fluorescens WCS374r, WCS417r, CHA0r, and P. aeruginosa $7 \mathrm{NSK} 2$, were compared for their abilities to induce systemic resistance in A. thaliana against bacterial speck caused by Pst (Ran et al. 2005a). The SA 'superproducer' P. fluorescens WCS374r could not induced resistance in A. thaliana, whereas strains WCS417r, CHA0r, and 7NSK2 could, and this phenotype was apparently associated with their ability to produce SA. Conversely, a SA ${ }^{-}$mutant of $7 \mathrm{NSK} 2$, MPFM1-569, still was able to trigger ISR. The possible involvement of SA in the induction of resistance was also evaluated using non SA-accumulating NahG plants, transformants that express the bacterial $N a h G$ gene that encodes salicylate hydroxylase converting SA into cathechol. Strains WCS417r, CHA0r, and 7NSK2 all induced resistance in NahG Arabidopsis. Likewise, WCS374r triggered ISR in these plants when grown at 33 or $36^{\circ} \mathrm{C}$. Thus, even though WCS374r can be manipulated to elicit ISR against bacterial speck in Arabidopsis, SA is not the primary determinant. Also for the other SA-producing strains, WCS417r, CHA0r and 7NSK2, bacterial determinants other than SA must be responsible for inducing resistance (Ran et al. 2005a).

SA-producing rhizobacterial strain $S$. marcescens 90-166 induces resistance against $P$. syringae pv. tabaci in both wild-type and NahG tobacco plants (Press et al. 1997). Moreover, a SA ${ }^{-}$mutant retained ISR-eliciting activity in cucumber against Colletotrichum orbiculare, and an ISR $^{-}$mutant, 90-166-2882, still produced SA. Also in tobacco against blue mold disease caused by Peronospora tabacina S. marcescens 90-166 significantly reduced disease severity in both wild type and NahG tobacco, indicating that systemically-induced resistance in tobacco to blue mold by strain $90-166$ is SAindependent (Zhang et al. 2002). In similar experiments it was demonstrated that protection of Arabidopsis against CMV by strain $90-166$ is independent of SA production (Ryu et al. 2004). In summary, SA produced by strain $90-166$ does not appear to be involved in the resistance induced by this strain in Arabidopsis, tobacco and cucumber (Press et al. 1997; Ryu et al. 2004; Zhang et al. 2002).
In conclusion, while PGPR strains producing SA in vitro have been identified frequently and the involvement of SA in both root colonization and elicitation of ISR response has been investigated, a clear role for PGPR-produced SA in ISR has not been established. In most cases the bacteria do not seem to produce SA in the rhizosphere, but instead they produce SA-containing siderophores (Fig. 1a). However, when SA is delivered in the rhizosphere by modified bacteria, like mutant KMPCH of $P$. aeruginosa 7NSK2 (Audenaert et al. 2002) or the SA producing transformant of P. fluorescens P3 (Maurhofer et al. 1998), it is bioactive in eliciting induced resistance. Moreover, root colonization by SA producing pseudomonads can elicit endogenous SA production in the root (Chen et al. 1999) (Fig. 1b). Thus, the presence of SA in the rhizosphere must be anticipated. Indeed, SA has been detected in root exudates of for example Arabidopsis (Badri et al. 2013), sugar beet (Khorassani et al. 2011), sunflower (Park et al. 1992) and watermelon (Ling et al. 2013). It thus appears that studies on SA in rhizosphere microbiology should not be restricted to SA produced by bacteria.

\section{SA and modulation of microbial interactions}

Whereas we have just seen that rhizobacterial produced SA can provoke headaches in rhizosphere scientists, exposure of bacteria to SA does result in more intriguing phenotypes. SA can induce a multiple antibiotic resistance phenotype, or reduce resistance to some antibiotics, and affect production of bacterial virulence factors (Price et al. 2000). However, such studies on effects of SA have focused on bacteria that are pathogenic in mammals. In that context SA may interfere with effective treatment of bacterial infections with antibiotics in patients treated with salicylates, or it can have a direct effect on pathogenesis. In a plant-microbe interactions context, we may have to consider that SA production by the plant influences antibiosis driven antagonism among members of the microbiome. Indeed, bacterial competition in natural environments seems to be fierce (Hibbing et al. 2010; Foster and Bell 2012). In an elegant study, Garbeva et al. (2011) demonstrated that $P$. fluorescens Pf0-1 responds differentially to different bacterial competitors. In the rhizosphere, inhibition of microbial plant pathogens by certain PGPR is based on production of antibiotics, and in some cases development of resistance 


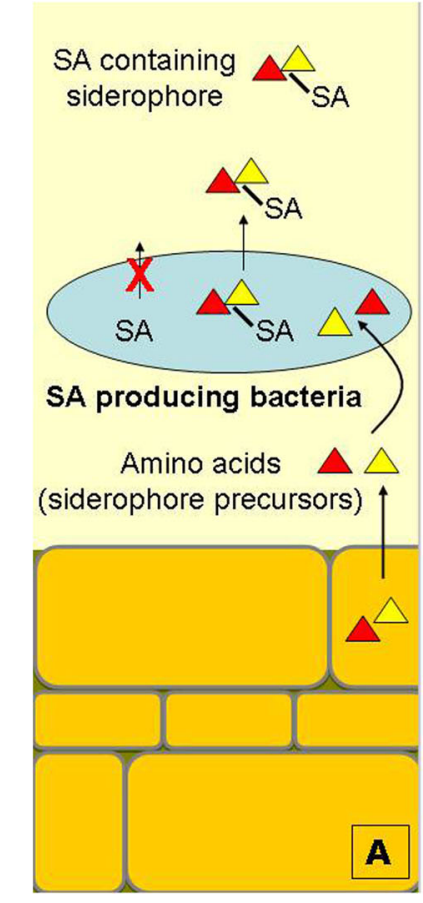

Fig. 1 a Although many bacteria that inhabit plant roots have the potential to produce salicylic acid (SA) in vitro, in the rhizosphere they will most likely not produce SA but instead excrete siderophores containing a SA moiety. This is postulated to be due to the presence of compounds in the root exudates that are precursors for such siderophores (Audenaert et al. 2002). b Colonization of the rhizosphere by certain bacteria (but also infection of

in the pathogen can interfere with the protective effect of the PGPR (Raaijmakers et al. 2002, 2009). Antibiosis thus seems a common phenomenon in rhizosphere microbial communities. Antibiotics are not only produced as weapons against other microbes but they are also important in signaling networks (Raaijmakers and Mazzola 2012; Baquero et al. 2013). A modulating effect of SA on these interactions may thus have significant impact on the composition and functioning of the rhizosphere microbiome.

The phenomenon that SA mediates resistance to antibiotics in $E$. coli has been known for decades (Rosner 1985; Cohen et al. 1993). Also for other pathogenic bacteria such effects have been reported. Exposure of $S$. marcescens to SA induced a phenotypic resistance to nalidixic acid and ciprofloxacin (Berlanga and Viñas 2000). In Salmonella choleraesuis multiple antibiotic resistance was induced by SA in some isolates, but for others SA had no effect (Tibbetts et al. 2003). SA also reduces sensitivity of Salmonella enterica to the antibiotic ciprofloxacin (Hartog et al.

\section{Shaping microbial communities}

Microbial Interactions

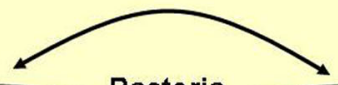

Bacteria

Antibiotic production Biofilm formation

Motility, etc,

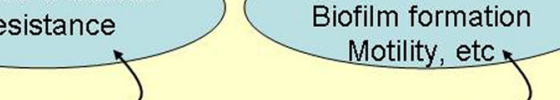

$S A$
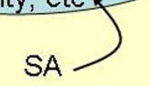

(2)

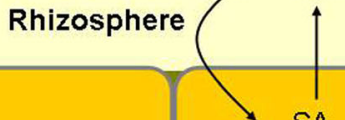

SA

B the plant by pathogens) can lead to SA production in the plant and subsequent deposition of SA in the rhizosphere. SA can influence different microbial activities including antibiotic production, biofilm formation and motility, all important for rhizosphere colonization, but also can modulate resistance to antibiotics. Thus SA can influence microbial interactions and play a significant role in shaping microbial community structure
2010). Similarly, antibiotic resistance is increased in Staphylococcus aureus in the presence of SA (Gustafson et al. 1999) due to specific up- and downregulation of genes involved in resistance to antimicrobials (Riordan et al. 2007). In M. tuberculosis SA reduced sensitivity to isoniazid, rifampin, ethambutol, streptomycin and $p$-aminosalicylate (Schaller et al. 2002). In this respect it is interesting to note that sensitivity to $p$-aminosalicylate in M. smegmatis is increased in knock-out mutants that no longer produce SA (Nagachar and Ratledge 2010). For the B. cepacia complex SA induces antibiotic resistance (Burns and Clark 1992) due to the induction of an antibiotic efflux pump (Nair et al. 2004). Induction of the CmeABC multidrug efflux pump is also the mechanism of SA-induced antibiotic resistance in Campylobacter jejuni (Shen et al. 2011). In a study on responses of Bacillus subtilis to SA, proteomic and transcriptomic analysis revealed changes that seemed related to resistance to SA itself (Duy et al. 2007). It was postulated that salicylate production by $P$. aeruginosa during infection may lead to a phenotype 
of antibiotic resistance (Martínez and Baquero 2002). For Helicobacter pylori growth was inhibited by SA, and in this case it increased susceptibility to the antibiotics amoxicillin, clarithromycin and metronidazole (Wang et al. 2003).

Also other traits of bacteria that are of importance in their environmental ecology are influenced by SA. Flagellar motility is an important trait for colonization of roots (De Weger et al. 1987; Lugtenberg and Kamilova 2009). SA inhibits motility in E. coli, Proteus mirabilis, Providencia rettgeri, Providencia stuartii and $P$. cepacia, but not that of $P$. aeruginosa (Kunin et al. 1995). Biofilm formation is important in the rhizosphere (Morris and Monier 2003). For Staphylococcus epidermidis adding SA to the growth medium resulted in inhibition of biofilm formation (Müller et al. 1998). In a study on biofilm formation by E. coli, Klebsiella pneumoniae, P. mirabilis, and $P$. aeruginosa, SA was shown to reduce biofilm production and to disrupt preformed biofilms (El-Banna et al. 2012). Quorum sensing, regulation of microbial gene expression in response to cell density, is another important driver of microbial activities in the rhizosphere (Pierson and Pierson 2007). Such activities include antibiotic production, biofilm formation, conjugation, motility, symbiosis, and virulence (Miller and Bassler 2001). SA was identified as a compound that can inhibit quorum sensing activity of the opportunistic human pathogen $P$. aeruginosa in a dose dependent manner (Yang et al. 2009). Also for the plant pathogen Agrobacterium tumefaciens SA was demonstrated to interfere with quorum sensing (Yuan et al. 2008). Other effects of SA on microbial functioning have been reported. In P. fluorescens CHA0, SA represses the production of 2,4-diacetylphloroglucinol, an antimicrobial metabolite that is important for control of soil borne disease by this PGPR (Schnider-Keel et al. 2000). Virulence of $P$. aeruginosa on A. thaliana is downregulated by SA (Prithiviraj et al. 2005b). Also resistance of Arabidopsis to infection by $S$. aureus may be mediated by a direct effect of SA on this gram-positive bacterium (Prithiviraj et al. 2005a). Again such an impact of SA can greatly influence microbial and interkingdom interactions in the rhizosphere microbiome. Thus, whereas it seems that the rhizobacterial strains studied do not produce SA in the rhizosphere, specific activities of the rhizosphere microbiome may well be influenced by SA produced by the plant (Fig. 1b).

\section{Concluding remarks}

Despite the vast knowledge on effects of SA on both animals and plants, relatively little is known about its effect on micro-organisms, including fungi and bacteria. A number of plant associated bacteria have been demonstrated to have the ability to produce significant amounts of SA, but mostly co-regulated with the biosynthesis of siderophores that contain a salicylate moiety. Mutants that no longer produce SA and/or the SA containing siderophore do not differ significantly from the wild-type with regard to their ecology in the rhizosphere. Li et al. (2011) describe the production of the SA containing antibiotic promysalin that is produced by P. putida RW10S1. The involvement of promysalin in the ecology of the producer is intriguing, since it promotes swarming and biofilm formation by the producing strain and at the same time shows toxicity specific to Pseudomonas spp. Thus the interspecies activity of microbially-produced SA containing compounds is not limited to siderophores. The modulation of bacterial motility, biofilm formation, quorum sensing, and resistance to antibiotics by SA suggests that this molecule could be one of the key components involved in assembling the rhizosphere microbiome. Given the recent attention for the rhizosphere microbiome and how it is influenced by plant signals (Bakker et al. 2013; Berendsen et al. 2012; Bulgarelli et al. 2013; Doornbos et al. 2011, 2012; Mendes et al. 2011, 2013), the role of plant derived SA in microbiome assembly deserves to be studied in detail.

Acknowledgments The work in LongXian Ran's group was partially supported by National Natural Science Foundation of China (NSFC, No.31070574). Research in Jesús MercadoBlanco's lab was supported by grants P07-CVI-02624 from Junta de Andalucía (Spain) and AGL2009-07275 from Spanish MICINN/MINECO, both co-financed by ERDF of the EU.

\section{References}

Adilakshmi T, Ayling PD, Ratledge C (2000) Mutational analysis of a role for salicylic acid in iron metabolism of Mycobacterium smegmatis. J Bacteriol 182:264-271

An CF, Mou ZL (2011) Salicylic acid and its function in plant immunity. J Integr Plant Biol 53:412-428

Ankenbauer RG, Cox CD (1988) Isolation and characterization of Pseudomonas aeruginosa mutants requiring salicylic acid for pyochelin biosynthesis. J Bacteriol 170:5364-5367 
Anthoni U, Christophersen C, Nielsen PH, Gram L, Petersen BO (1995) Pseudomonine, an isoxazolidone with siderophoric activity from Pseudomonas fluorescens $\mathrm{AH} 2$ isolated from Lake Victorian Nile perch. J Nat Prod 58:1786-1789

Audenaert K, Pattery T, Cornelis P, Höfte M (2002) Induction of systemic resistance to Botrytis cinerea by Pseudomonas aeruginosa 7NSK2: Role of salicylic acid, pyochelin, and pyocyanin. Mol Plant-Microbe Interact 15:1147-1156

Badri DV, Chaparro JM, Zhang R, Shen Q, Vivanco JM (2013) Application of natural blends of phytochemicals derived from the root exudates of Arabidopsis to the soil reveal that phenolic related compounds predominantly modulate the soil microbiome. J Biol Chem 288:4502-4512

Bagg A, Neilands JB (1987) Ferric uptake regulation protein acts as a repressor, employing iron (II) as a cofactor to bind the operator of an iron transport operon in Escherichia coli. Biochemistry 26:5471-5477

Bakker PAHM, Ran LX, Pieterse CMJ, Van Loon LC (2003) Understanding the involvement of induced systemic resistance in rhizobacteria-mediated biocontrol of plant diseases. Can J Plant Pathol 25:5-9

Bakker PAHM, Pieterse CMJ, Van Loon LC (2007a) Induced systemic resistance by fluorescent Pseudomonas spp. Phytopathology 97:239-243

Bakker PAHM, Raaijmakers JM, Bloemberg GV, Höfte M, Lemanceau P, Cooke M (2007b) New perspectives and approaches in plant growth-promoting rhizobacteria research. Eur J Plant Pathol 119:241-242

Bakker PAHM, Berendsen RL, Doornbos RF, Wintermans PCA, Pieterse CMJ (2013) The rhizosphere revisited: root microbiomics. Front Plant Sci 4:165

Baquero F, Tedim AP, Coque TM (2013) Antibiotic resistance shaping multi-level population biology of bacteria. Front Microbiol 4:15

Berendsen RL, Pieterse CMJ, Bakker PAHM (2012) The rhizosphere microbiome and plant health. Trends Plant Sci 17: $478-486$

Berendsen RL, Schrier N, Kalkhove SIC, Lugones LG, Baars JP, Zijlstra C, De Weerdt M, Wösten HAB, Bakker PAHM (2013) Absence of induced resistance in Agaricus bisporus against Lecanicillium fungicola. Anton Leeuw Int J G 103: 539-550

Berlanga M, Viñas M (2000) Salicylate induction of phenotypic resistance to quinolones in Serratia marcescens. J Antimicrob Chemother 46:279-282

Brandel J, Humbert N, Elhabiri M, Schalk IJ, Mislin GLA, Albrecht-Gary AM (2012) Pyochelin, a siderophore of Pseudomonas aeruginosa: physicochemical characterization of the iron(iii), copper(ii) and zinc(ii) complexes. Dalton Trans 41:2820-2834

Bulgarelli D, Schlaeppi K, Spaepen S, Loren V, van Themaat E, Schulze-Lefert P (2013) Structure and functions of the bacterial microbiota of plants. Annu Rev Plant Biol 64:807-837

Bultreys A, Gheysen I, De Hoffmann E (2006) Yersiniabactin production by Pseudomonas syringae and Escherichia coli, and description of a second yersiniabactin locus evolutionary group. Appl Environ Microbiol 72:3814-3825

Burns JL, Clark DK (1992) Salicylate-inducible antibiotic resistance in Pseudomonas cepacia associated with absence of a pore-forming outer membrane protein. Antimicrob Agents Chemother 36:2280-2285
Buysens S, Huengens K, Poppe J, Höfte M (1996) Involvement of pyochelin and pyoverdin in suppression of Pythium-induced damping-off of tomato by Pseudomonas aeruginosa 7NSK2. Appl Environ Microbiol 62:865-871

Carmi R, Varmeli S, Levy E, Gough FJ (1994) (1)-(S)dihydroaeruginoic acid, an inhibitor of Septoria tritici and other phytopathogenic fungi and bacteria, produced by Pseudomonas fluorescens. J Nat Prod 57:1200-1205

Castignetti D (1997) Probing of Pseudomonas aeruginosa, Pseudomonas aureofaciens, Burkholderia (Pseudomonas) cepacia, Pseudomonas fluorescens, and Pseudomonas putida with the ferripyochelin receptor A gene and the synthesis of pyochelin in Pseudomonas aureofaciens, Pseudomonas fluorescens, and Pseudomonas putida. Curr Microbiol 34: 250-257

Chambers CE, McIntyre DD, Mouck M, Sokol PA (1996) Physical and structural characterization of yersiniophore, a siderophore produced by clinical isolates of Yersina enterocolitica. BioMetals 9:157-167

Chen C, Bélanger RR, Benhamou N, Paulitz TC (1999) Role of salicylic acid in systemic resistance induced by Pseudomonas spp. against Pythium aphanidermatum in cucumber roots. Eur J Plant Pathol 105:477-486

Chen A, Zheng Z, Huang J, Lai Z, Fan B (2009) Biosynthesis of salicylic acid in plants. Plant Signal Behav 4:493-496

Chipperfield JR, Ratledge C (2000) Salicylic acid is not a bacterial siderophore: a theoretical study. BioMetals 13:165

Cohen SP, Levy SB, Foulds J, Rosner JL (1993) Salicylate induction of antibiotic resistance in Escherichia coli: activation of the mar operon and a mar-independent pathway. J Bacteriol 175:7856-7862

Cox CD, Graham R (1979) Isolation of an iron-bindong compound from Pseudomonas aeruginosa. J Bacteriol 137:357364

Cox CD, Rinehart KL, Moore ML, Cook JC (1981) Pyochelin: novel structure of an iron-chelating growth promoter for Pseudomonas aeruginosa. Proc Natl Acad Sci U S A 78: 4256-4260

De Lorenzo V, Wee S, Herrero M, Neilands JB (1987) Operator sequences of the aerobactin operon of plasmid ColV-K30 binding the ferric uptake regulation (fur) repressor. J Bacteriol 169:2624-2630

De Meyer G, Höfte M (1997) Salicylic acid produced by the rhizobacterium Pseudomonas aeruginosa 7NSK2 induces resistance to leaf infection by Botrytis cinerea on bean. Phytopathology 87:588-593

De Meyer G, Audenaert K, Höfte M (1999a) Pseudomonas aeruginosa 7NSK2 induced systemic resistance in tobacco depends on in planta salicylic acid accumulation but is not associated with PRla expression. Eur J Plant Pathol 105: 513-517

De Meyer G, Capieau C, Audenaert K, Buchala A, Métraux JP, Höfte M (1999b) Nanogram amounts of salicylic acid produced by the rhizobacterium Pseudomonas aeruginosa 7NSK2 activate the systemic acquired resistance pathway in bean. Mol Plant-Microbe Interact 12:450-458

De Vleesschauwer D, Höfte M (2009) Rhizobacteria-induced systemic resistance. Adv Bot Res 51:223-281

De Vleesschauwer D, Djavaheri M, Bakker PAHM, Höfte M (2008) Pseudomonas fluorescens WCS374r-induced systemic resistance in rice against Magnaporthe oryzae is based on 
pseudobactin-mediated priming for a salicylic acidrepressible multifaceted defense response. Plant Physiol 148:1996-2012

De Weger LA, Van der Vlugt CIM, Wijfjes AHM, Bakker PAHM, Schippers B, Lugtenberg B (1987) Flagella of a plantgrowth-stimulating Pseudomonas fluorescens strain are required for colonization of potato roots. J Bacteriol 169:27692773

Dempsey DA, Vlot AC, Wildermuth MC, Klessig DF (2011) Salicylic acid biosynthesis and metabolism. The Arabidopsis Book e0156 doi: 10.1199/Tab.0156

Djavaheri M, Mercado-Blanco J, Versluis C, Meyer J-M, Van Loon LC, Bakker PAHM (2012) Iron-regulated metabolites produced by Pseudomonas fluorescens WCS374r are not required for eliciting induced systemic resistance against Pseudomonas syringae pv. tomato in Arabidopsis. Microbiol Open 1:311-325

Doornbos RF, Geraats BPJ, Kuramae EE, Van Loon LC, Bakker PAHM (2011) Effects of jasmonic acid, ethylene, and salicylic acid signaling on the rhizosphere bacterial community of Arabidopsis thaliana. Mol Plant-Microbe Interact 24: 395-407

Doornbos RF, Van Loon LC, Bakker PAHM (2012) Impact of root exudates and plant defense signaling on bacterial communities in the rhizosphere. Agron Sustain Dev 32:227-243

Drechsel H, Stephan H, Lotz R, Haag H, Zahner H, Hankte K, Jung G (1995) Structure elucidation of yersiniabactin, a siderophore from highly virulent Yersinia strains. Liebigs Ann 1727-1733

Duffy BK, Défago G (1999) Environmental factors modulating antibiotic and siderophore biosynthesis by Pseudomonas fluorescens biocontrol strains. Appl Environ Microbiol 65: 2429-2438

Duijff BJ, Recorbet G, Bakker PAHM, Loper JE, Lemanceau P (1999) Microbial antagonism at the root level is involved in suppression of Fusarium wilt by the combination of nonpathogenic Fusarium oxysporum Fo47 and Pseudomonas putida WCS358. Phytopathology 89:1073-1079

Durrant WE, Dong X (2004) Systemic acquired resistance. Annu Rev Phytopathol 42:185-209

Duy NV, Mader U, Tran NP, Cavin JF, Tam LT, Albrecht D, Hecker M, Antelmann H (2007) The proteome and transcriptome analysis of Bacillus subtilis in response to salicylic acid. Proteomics 7:698-710

El-Banna T, Sonbol FI, El-Aziz AAA, Abo-Kamar A, Seif-Eldin DW (2012) Effect of the combination of salicylate with aminoglycosides on bacterial adhesion to urinary catheters. Int Res J Pharm 2:39-45

Farmer KL, Thomas MS (2004) Isolation and characterization of Burkholderia cenocepacia mutants deficient in pyochelin production: pyochelin biosynthesis is sensitive to sulfur availability. J Bacteriol 186:270-277

Forchetti G, Masciarelli O, Izaguirre MJ, Alemano S, Alvarez D, Abdala G (2010) Endophytic bacteria improve seedling growth of sunflower under water stress, produce salicylic acid, and inhibit growth of pathogenic fungi. Curr Microbiol 61:485-493

Foster KR, Bell T (2012) Competition, not cooperation, dominates interactions among culturable microbial species. Curr Biol 22:1845-1850
Fuster V, Sweeny JM (2011) Aspirin: a historical and contemporary therapeutic overview. Circulation 123:768-778

Gaffney T, Friedrich L, Vernooij B, Negrotto D, Nye G, Ukness S, Ward E, Kessmann H, Ryals J (1993) Requirement of salicylic acid for the induction of systemic acquired resistance. Science 261:754-756

Gaille C, Kast P, Haas D (2002) Salicylate biosynthesis in Pseudomonas aeruginosa -purification and characterization of PchB, a novel bifunctional enzyme displaying isochorismate pyruvate-lyase and chorismate mutase activities. J Biol Chem 277:21768-21775

Gaille C, Reimmann C, Haas D (2003) Isochorismate synthase (PchA), the first and rate-limiting enzyme in salicylate biosynthesis of Pseudomonas aeruginosa. J Biol Chem 278: 16893-16898

Gamliel A, Katan J (1992) Influence of seed and root exudates on fluorescent pseudomonads and fungi in solarized soil. Phytopathology 82:320-327

Garbeva P, Silby MW, Raaijmakers JM, Levy SB, De Boer W (2011) Transcriptional and antagonistic responses of Pseudomonas fluorescens Pf0-1 to phylogenetically different bacterial competitors. ISME J 5:973-985

Garcion C, Métraux JP (2006) Salicylic acid. In: Hedden P, Thomas SG (eds) Plant hormone signaling. Blackwell, Oxford, pp 229-255

Geels FP, Schippers B (1983) Reduction in yield depressions in high frequency potato cropping soil after seed tuber treatments with antagonistic fluorescent Pseudomonas spp. Phytopathol Z 108:207-214

Gehring AM, DeMoll E, Fetherston JD, Mori I, Mayhew GF, Blattner FR, Walsh CT, Perry RD (1998) Iron acquisition in plague: modular logic in enzymatic biogenesis of yersiniabactin by Yersinia pestis. Chem Biol 5:573-586

Gershon H, Parmegiani R (1962) Antimicrobial activity of 8quinolinols, salicylic acids, hydroxynaphthoic acids, and salts of selected quinolinols with selected hydroxy-acids. Appl Microbiol 10:348-353

Gustafson JE, Candelaria PV, Fisher SA, Goodridge JP, Lichocik TM, McWilliams TM, Price CDT, O'Brien FG, Grubb WB (1999) Growth in the presence of salicylate increases fluoroquinolone resistance in Staphylococcus aureus. Antimicrob Agents Chemother 43:990-992

Harrison AJ, Yu M, Gårdenborg T, Middleditch M, Ramsay RJ, Baker EN, Lott JS (2006) The structure of MbtI from Mycobacterium tuberculosis, the first enzyme in the biosynthesis of the siderophore mycobactin, reveals it to be a salicylate synthase. J Bacteriol 188:6081-6091

Hartog E, Menashe O, Kler E, Yaron S (2010) Salicylate reduces the antimocrobial activity of ciproflaxalin against extracellular Salmonelle enterica serovar Typhimurium, but not against Salmonella in macrophages. J Antimicrob Chemother 65: 888-896

Hayat S, Ahmad A, Alyemeni MN (2013) Salicylic acid, plant growth and development. Springer, Dordrecht

Hibbing ME, Fuqua C, Parsek MR, Peterson SB (2010) Bacterial competition: surviving and thriving in the microbial jungle. Nat Rev Microbiol 8:15-25

Himejina M, Kubo I (1991) Antibacterial agents from the cashew Anacardium occidentale (Anacardiaceae) nut shell oil. J Agric Food Chem 39:418-421 
Hinsinger P, Plassard C, Tang C, Jaillard B (2003) Origins of root-mediated $\mathrm{pH}$ changes in the rhizosphere and their responses to environmental constraints: a review. Plant Soil 248:43-59

Hudson AT, Bentley R (1970) Utilization of shikimic acid for the formation of mycobactin $\mathrm{S}$ and salicylic acid by Mycobacterium smegmatis. Biochemistry 9:3984-3987

Jack DB (1997) One hundred years of aspirin. Lancet 350:437439

Jones AM, Lindow SE, Wildermuth MC (2007) Salicylic acid, yersiniabactin, and pyoverdin production by the model phytopathogen Pseudomonas syringae pv. tomato DC3000: synthesis, regulation, and impact on tomato and Arabidopsis host plants. J Bacteriol 189:6773-6786

Keller-Schierlein W, Hagmann L, Zähner H, Huhn W (1988) Maduraferrin, a novel siderophore from Acinomadura madurae. Helv Chim Acta 71:1528-1534

Kerbarh O, Ciulli A, Howard NI, Abell C (2005) Salicylate biosynthesis: overexpression, purification, and characterization of Irp9, a bifunctional salicylate synthase from Yersinia enterocolitica. J Bacteriol 187:5061-5066

Khorassani R, Hettwer U, Ratzinger A, Steingrobe B, Karlovsky P, Claassen N (2011) Citramalic acid and salicylic acid in sugar beet root exudates solubilize soil phosphorus. BMC Plant Biol 11:121

Kloepper JW, Ryu CM, Zhang S (2004) Induced systemic resistance and promotion of plant growth by Bacillus spp. Phytopathology 94:1259-1266

Kunin CM, Tong HH, Bakaletz LO (1995) Effect of salicylate on expression of flagella by Escherichia coli and Proteus, Providencia, and Pseudomonas spp. Infect Immun 63: 1796-1799

Künzler DE, Sasso S, Gamper M, Hilvert D, Kast P (2005) Mechanistic insights into the isochorismate pyruvate lyase activity of the catalytically promiscuous PchB from combinatorial mutagenesis and selection. J Biol Chem 38:3282732834

Lamers JG, Schippers B, Geels FP (1988) Soil-borne diseases of wheat in the Netherlands and results of seed bacterization with psedumonads against Gaeumannomyces graminis var. tritici, associated with disease resistance. In: Jorna ML, Slootmaker LAJ (eds) Cereal breeding related to integrated cereal production. Pudoc, Wageningen, pp 134-139

Le Dang Q, Son SW, Cheon HM, Choi GJ, Choi YH, Jang KS, Lim CH, Kim JC (2011) Pyochelin isolated from Burkholderia arboris KRICT1 carried by pine wood nematodes exhibits phytotoxicity in pine callus. Nematology 13 : 521-528

Lee H-I, León J, Raskin I (1995) Biosynthesis and metabolism of salicylic acid. Proc Natl Acad Sci USA 92:4076-4079

Leeman M, Den Ouden FM, Van Pelt JA, Dirkx FPM, Steijl H, Bakker PAHM, Schippers B (1996) Iron availability affects induction of systemic resistance against fusarium wilt of radish by Pseudomonas fluorescens. Phytopathology 86 : 149-155

Li W, Estrada-de los Santos P, Matthijs S, Xie GL, Busson R, Cornelis P, Rozenski J, de Mot R (2011) Promysalin, a salicylate-containing Pseudomonas putida antibiotic, promotes surface colonization and selectively targets other Pseudomonas. Chem Biol 18:1320-1330
Ling N, Zhang W, Wang D, Mao J, Huang Q, Guo S, Shen Q (2013) Root exudates from grafted-root watermelon showd a certain controbution in inhibiting Fusarium oxysporum f.sp. niveum. PLoS ONE 8:e63383

Loper JE, Henkels MD (1997) Availability of iron to Pseudomonas fluorescens in rhizosphere and bulk soil evaluated with an ice nucleation reporter gene. Appl Environ Microbiol 63:99-105

Loper JE, Hassan KA, Mavrodi DV, Davis EW II, Lim CK, Shaffer BT, Elbourne LDH, Stockwell VO, Hartney SL, Breakwell K, Henkels MD, Tetu SG, Rangel LI, Kidarsa TA, Wilson NL, Van de Mortel JE, Song C, Blumhagen R, Radune D, Hostetler JB, Brinkac LM, Durkin AS, Kluepfel DA, Wechter WP, Anderson AJ, Kim YC, Pierson LS III, Pierson EA, Lindow SE, Kobayashi DY, Raaijmakers JM, Weller DM, Thomashow LS, Allen AE, Paulsen IT (2012) Comparative genomics of plant-associated Pseudomonas spp.: Insights into diversity and inheritance of traits involved in multitrophic interactions. PLoS Genet 8:e1002784

López-Escudero FJ, Mercado-Blanco J (2011) Verticillium wilt of olive: a case study to implement an integrated strategy to control a soil-borne pathogen. Plant Soil 344:1-50

Lugtenberg B, Kamilova F (2009) Plant-growth-promoting rhizobacteria. Annu Rev Microbiol 63:541-556

Mahdi JG (2010) Medicinal potential of willow: a chemical perspective of aspirin discovery. J Saudi Chem Soc 14:317-322

Marshall BJ, Ratledge C (1971) Conversion of chorismic acid and isochorismic acid to salicylic-acid by cell-free extracts of Mycobacterium smegmatis. Biochim Biophys Acta 230: 643-645

Marshall BJ, Ratledge C (1972) Salicylic acid biosynthesis and its control in Mycobacterium smegmatis. Biochim Biophys Acta 264:106-116

Martínez JL, Baquero F (2002) Interactions among strategies associated with bacterial infection: pathogenicity, epidemicity, and antibiotic resistance. Clin Microbiol Rev 15:647-679

Marugg JD, van Spanje M, Hoekstra WPM, Schippers B, Weisbeek PJ (1985) Isolation and analysis of genes involved in siderophore biosynthesis in plant-growth-stimulating Pseudomonas putida WCS358. J Bacteriol 164:563-570

Matthijs S, Laus G, Meyer J-M, Abbaspour K, Schafer M, Budzikiewicz H, Cornelis P (2009) Siderophore-mediated iron acquisition in the entomopathogenic bacterium Pseudomonas entomophila L48 and its close relative Pseudomonas putida KT2440. Biometals 22:951-964

Maurhofer M, Hase C, Meuwly P, Metraux JP, Défago G (1994) Induction of systemic resistance of tobacco to tobacco necrosis virus by the root-colonizing Pseudomonas fluorescens strain CHA0: Influence of the gacA gene and of pyoverdine production. Phytopathology 84:139-146

Maurhofer M, Reimann C, Schimidli-Sachrer P, Heeb S, Haas D, Défago G (1998) Salicylic acid biosynthesis genes expressed in Pseudomonas fluorescens strain P3 improve the induction of systemic resistance in tobacco against tobacco necrosis virus. Phytopathology 88:678-684

Mendes R, Kruijt M, De Bruijn I, Dekkers E, Van der Voort M, Schneider JHM, Piceno YM, DeSantis TZ, Andersen GL, Bakker PAHM, Raaijmakers JM (2011) Deciphering the rhizosphere microbiome for disease suppressive bacteria. Science 332:1097-1100 
Mendes R, Garbeva P, Raaijmakers JM (2013) The rhizosphere microbiome: significance of plant-beneficial, plantpathogenic and human-pathogenic microorganisms. FEMS Microbiol Rev 37:634-663

Mercado-Blanco J, Van der Drift KM, Olsson PE, Thomas-Oates JE, Van Loon LC, Bakker PAHM (2001) Analysis of the pms CEAB gene cluster involved in biosynthesis of salicylic acid and the siderophore pseudomonine in the biocontrol strain Pseudomonas fluorescens WCS374. J Bacteriol 183: 1909-1920

Mercado-Blanco J, Rodríguez-Jurado D, Hervás A, Jiménez-Díaz RM (2004) Suppression of Verticillium wilt in olive planting stocks by root-associated fluorescent Pseudomonas spp. Biol Control 30:474-486

Meyer J-M, Abdallah MA (1978) The fluorescent pigment of Pseudomonas fluorescens: biosynthesis, purification and physicochemical properties. J Gen Microbiol 107:319-328

Meyer J-M, Azelvandre P, Georges C (1992) Iron metabolism in Pseudomonas: salicylic acid, a siderophore of Pseudomonas fluorescens CHA0. Biofactors 4:23-27

Miller MB, Bassler BL (2001) Quorum sensing in bacteria. Annu Rev Microbiol 55:165-199

Morris CE, Monier JM (2003) The ecological significance of biofilm formation by plant-associated bacteria. Annu Rev Phytopathol 41:429-453

Müller E, Al-Attar J, Wolff AG, Farber BF (1998) Mechanisms of salicylate-mediated inhibition of biofilm in Staphylococcus epidermidis. J Infect Dis 177:501-503

Müller-Schwarze D, Sun L (2003) The beaver, natural history of a wetlands engineer. Cornell University Press, Ithaca

Nagachar N, Ratledge C (2010) Knocking out salicylate biosynthesis genes in Mycobacterium smegmatis induceds hypersensitivity to $p$-aminosalicylate (PAS). FEMS Microbiol Lett 311:193-199

Nair BM, Cheung KJ, Griffith A, Burns JL (2004) Salicylate induces an antibiotic efflux pump in Burkholderia cepacia complex genomovar III (B. cenocepacia). J Clin Invest 113: 464-473

Nandhini S, Sendhilvel V, Babu S (2012) Endophytic bacteria from tomato and their efficacy against Fusarium oxysporum f.sp. lycopersici, the wilt pathogen. J Biopest 5:178-185

Okujo N, Saito M, Yamamoto S, Yoshida T, Miyoshi S, Shinoda S (1994) Structure of vulnibactin, a new polyamine-containing siderophore from Vibrio vulnificus. BioMetals 7:109-116

Oostendorp M, Kunz W, Dietrich B, Staub T (2001) Induced disease resistance in plants by chemicals. Eur J Plant Pathol 107:19-28

Park KH, Moody K, Kim SC, Kim KU (1992) Allelopathic activity and determination of allelochemicals from sunflower (Helianthus annuus L.) root exudates. Korean J Weed Sci 12: 173-182

Pelludat C, Brem D, Heesemann J (2003) Irp9, encoded by the high-pathogenicity island of Yersinia enterocolitica is able to convert chorismate into salicylate, the precursor of the siderophore yersiniabactin. J Bacteriol 18:5648-5653

Person T, Neilands JB (1979) Revised structure of a catecholamide spermidine siderophore from Paracoccus denitrificans. Tetrahedron Lett 50:485-4808

Pierson LS III, Pierson EA (2007) Roles of diffusible signals in communication among plant-associated bacteria. Phytopathology 97:227-232
Pieterse CMJ, Van Wees SCM, Hoffland E, Van Pelt JA, Van Loon LC (1996) Systemic resistance in Arabidopsis induced by biocontrol bacteria is independent of salicylic acid accumulation and pathogenesis-related gene expression. Plant Cell 8: 1225-1237

Press CM, Wilson M, Tuzun S, Kloepper JW (1997) Salicylic acid produced by Serratia marcescens $90-166$ is not the primary determinant of induced systemic resistance in cucumber or tobacco. Mol Plant-Microbe Interact 10:761-768

Price CTD, Lee IR, Gustafson JE (2000) The effects of salicylate on bacteria. Int J Biochem Cell Biol 32:1029-1043

Prieto P, Mercado-Blanco J (2008) Endophytic colonization of olive roots by the biocontrol strain Pseudomonas fluorescens PICF7. FEMS Microbiol Ecol 64:297-306

Prieto P, Navarro-Raya C, Valverde-Corredor A, Amyotte SG, Dobinson KF, Mercado-Blanco J (2009) Colonization process of olive tissues by Verticillium dahliae and its in planta interaction with the biocontrol root endophyte Pseudomonas fluorescens PICF7. Microb Biotechnol 2:499-511

Prithiviraj B, Bais HP, Jha AK, Vivanco JM (2005a) Staphylococcus aureus pathogenicity on Arabidopsis thaliana is mediated either by a direct effect of salicylic acid on the pathogen or by SA-dependent, NPR1-independent host responses. Plant J 42:417-432

Prithiviraj B, Bais HP, Weir T, Suresh B, Najarro EH, Dayakar BV, Schweizer HP, Vivanco JM (2005b) Down regulation of virulence factors of Pseudomonas aeruginosa by salicylic acid attenuates its virulence on Arabidopsis thaliana and Caenorhabditis elegans. Infect Immun 73:5319-5328

Quadri LE, Sello J, Keating TA, Weinreb PH, Walsh CT (1998) Identification of a Mycobacterium tuberculosis gene cluster encoding the biosynthetic genes for assembly of the virulenceconferring siderophore mycobactin. Chem Biol 5:631-645

Raaijmakers JM, Mazzola M (2012) Diversity and natural functions of antibiotics produced by beneficial and plant pathogenic bacteria. Annu Rev Phytopathol 50:403-424

Raaijmakers JM, Van der Sluis I, Koster M, Bakker PAHM, Weisbeek PJ, Schippers B (1995) Utilization of heterologous siderophores and rhizosphere competence of fluorescent Pseudomonas spp. Can J Microbiol 41:126-135

Raaijmakers JM, Vlami M, De Souza JT (2002) Antibiotic production by bacterial biocontrol agents. Anton Leeuw Int J G 81:537-547

Raaijmakers JM, Paulitz TC, Steinberg C, Alabouvette C, Moënne-Loccoz Y (2009) The rhizosphere: a playground and battlefield for soilborne pathogens and beneficial microorganisms. Plant Soil 321:341-361

Ran LX, Van Loon LC, Bakker PAHM (2005a) No role for bacterially produced salicylic acid in rhizobacterial induction of systemic resistance in Arabidopsis. Phytopathology 95: 1349-1355

Ran LX, Li ZN, Wu GJ, Van Loon LC, Bakker PAHM (2005b) Induction of systemic resistance against bacterial wilt in Eucalyptus urophylla by fluorescent Pseudomonas spp. Eur J Plant Pathol 113:59-70

Ran LX, Liu CY, Wu GJ, Van Loon LC, Bakker PAHM (2005c) Suppression of bacterial wilt in Eucalyptus urophylla by fluorescent Pseudomonas spp. in China. Biol Control 32: $111-120$

Raskin I (1992) Role of salicylic acid in plants. Annu Rev Plant Physiol Plant Mol Biol 43:439-463 
Ratledge C (1969) The biosynthesis of salicylic acid in Mycobacterium smegmatis via the shikimic acid pathway. Biochim Biophys Acta 192:148-150

Ratledge C, Hall MJ (1971) Influence of metal ions on the formation of mycobactin and salicylic acid in Mycobacterium smegmatis grown in static culture. J Bacteriol 108:314-419

Ratledge C, Hall MJ (1972) Isolation and properties of auxotrophic mutants of Mycobacterium smegmatis requiring either salicylic acid or mycobactin. J Gen Microbiol 72: $143-150$

Ratledge C, Winder FG (1962) The accumulation of salicylic acid by mycobacteria during growth on iron-deficient medium. Biochem J 84:501-506

Reimmann C, Maurhofer M, Schmidli P, Gaille C, Haas D, Défago G (1997) Role of salicylate produced by Pseudomonas fluorescens in the suppression of tobacco diseases. In: Ogoshi A, Kobayashi K, Homma Y, Kodama F, Kondo N, Akino S (eds) Plant growth-promoting rhizobacteria: present status and future prospects. Sapporo, Japan, pp 248-250

Reimmann C, Serino L, Beyeler M, Haas D (1998) Dihydroaeruginoic acid synthetase and pyochelin synthetase, products of the pchEF genes, are induced by extracellular pyochelin in Pseudomonas aeruginosa. Microbiology 144:3135-3148

Riordan JT, Muthaiyan A, Van Voorhies W, Price CT, Graham JE, Wilkinson BJ, Gustafson JE (2007) Response of Staphylococcus aureus to salicylate challenge. J Bacteriol 189:220-227

Rivas-San Vicente M, Plasencia J (2011) Salicylic acid beyond defence: its role in plant growth and development. J Exp Bot 62:3321-3338

Rosner JL (1985) Nonheritable resistance to chloramphenicol and other antibiotics induced by salicylates and other chemotactic repellents in Escherichia coli K-12. Proc Natl Acad Sci U S A 82:8771-8774

Ryu C-M, Murphy JF, Mysore KS, Kloepper JW (2004) Plant growth-promoting rhizobacteria systemically protect Arabidopsis thaliana against Cucumber mosaic virus by a salicylic acid and NPR1-independent and jasmonic aciddependent signaling pathway. Plant J 39:381-392

Saikia R, Singh T, Kumar R, Srivastava J, Srivastava AK, Singh K, Arora DK (2003) Role of salicylic acid in systemic resistance induced by Pseudomonas fluorescens against Fusarium oxysporum f. sp. ciceri in chickpea. Microbiol Res 158:203213

Saikia R, Srivastava AK, Singh K, Arora DK, Lee MW (2005) Effect of iron availability on induction of systemic resistance to fusarium wilt of chickpea by Pseudomonas spp. Mycobiology 33:35-40

Saikia R, Kumar R, Arora DK, Gogoi DK, Azad P (2006) Pseudomonas aeruginosa inducing rice resistance against Rhizoctonia solani: production of salicylic acid and peroxidases. Folia Microbiol 51:375-380

Sattely ES, Walsh CT (2008) A latent oxazoline electrophile for N$\mathrm{O}-\mathrm{C}$ bond formation in pseudomonine biosynthesis. J Am Chem Soc 130:12282-12284

Saxena B, Mayuranki M, Modi VV (1986) Isolation and characterization of siderophores from Azospirillum lipoferum D-2. J Gen Microbiol 132:2219-2224

Schaller A, Sun Z, Yang Y, Somoskovi A, Zhang Y (2002) Salicylate reduces susceptibility to multiple antituberculosis drugs. Antimicrob Agents Chemother 46:2636-2639
Schilirò E, Ferrara M, Nigro F, Mercado-Blanco J (2012) Genetic responses induced in olive roots upon colonization by the biocontrol endophytic bacterium Pseudomonas fluorescens PICF7. PLoS ONE 7:e48646

Schnider-Keel U, Seematter A, Maurhofer M, Blumer C, Duffy B, Gigot-Bonnefoy C, Reimmann C, Notz R, Défago G, Haas D, Keel C (2000) Autoinduction of 2, 4-diacetylphloroglucinol biosynthesis in the biocontrol agent Pseudomonas fluorescens CHA0 and repression by the bacterial metabolites salicylate and pyoluteorin. J Bacteriol 182:1215-1225

Serino L, Reimmann C, Baur H, Beyeler M, Visca P, Haas D (1995) Structural genes for salicylate biosynthesis from chorismate in Pseudomonas aeruginosa. Mol Gen Genet 249:217-228

Serino L, Reimmann C, Visca P, Beyeler M, della Chiesa V, Haas D (1997) Biosynthesis of pyochelin and dihydroaeruginoic acid requires the iron-regulated $p c h D C B A$ operon in Pseudomonas aeruginosa. J Bacteriol 179:248-257

Shen Z, Pu XY, Zhang Q (2011) Salicylate functions as an efflux pupm inducer and promotes the emergence of fluoroquinolone-resistant Campylobacter jejuni mutants. Appl Environ Microbiol 77:7128-7133

Snow GA (1965) Isolation and structure of mycobactin T, a growth factor from Mycobacterium tuberculosis. Biochem J 97:166-175

Sokol PA, Lewis CJ, Dennis JJ (1992) Isolation of a novel siderophore from Pseudomonas cepacia. J Med Microbiol 36:184-189

Stutz EW, Défago G, Kern H (1986) Naturally occuring fluorescence pseudomonads involved in suppression of black root rot of tobacco. Phytopathology 76:181-185

Tibbetts RJ, Lin TL, Wu CC (2003) Phenotypic evidence for inducible multiple antimicrobial resistance in Salmonella choleraesuis. FEMS Microbiol Lett 218:333-338

Van Loon LC, Bakker PAHM (2005) Induced systemic resistance as a mechanism of disease suppression by rhizobacteria. In: Siddiqui ZA (ed) PGPR: biocontrol and biofertilization. Springer, Dordrecht, pp 39-66

Van Loon LC, Bakker PAHM, Pieterse CMJ (1998) Systemic resistance induced by rhizosphere bacteria. Annu Rev Phytopathol 36:453-483

Van Wees SCM, Pieterse CMJ, Trijssenaar A, Van't Westende YAM, Hartog F, Van Loon LC (1997) Differential induction of systemic resistance in Arabidopsis by biocontrol bacteria. Mol Plant-Microbe Interact 10:716-724

Verberne MC, Budi Muljono RA, Verpoorte R (1999) Salicylic acid biosynthesis. In: Hooykaas PPJ, Hall MA, Libbenga KR (eds) Biochemisty and molecular biology of plant hormones. Elsevier Science BV, Amsterdam, pp 295-314

Visca P, Ciervo A, Sanfilippo V, Orsi N (1993) Iron-regulated salicylate synthesis by Pseudomonas spp. J Gen Microbiol 139:1995-2001

Vlot A, Dempsey DA, Klessig DF (2009) Salicylic acid, a multifaceted hormone to combat disease. Annu Rev Phytopathol 47:177-206

Wang WH, Wong WM, Dailidiene D, Berg DE, Gu Q, Lai KC, Lam SK, Wong BCY (2003) Aspirin inhibits the growth of Helicobacter pylori and enhances its susceptibility to antimicrobial agents. Gut 52:490-495 
White RF (1979) Acetylsalicylic acid (aspirin) induces resistance to tobacco mosaic virus in tobacco. Virology 99: 410-412

Wildermuth MC (2006) Variations on a theme: synthesis and modification of plant benzoic acids. Curr Opin Plant Biol 9: 288-296

Wildermuth MC, Dewdney J, Wu G, Ausubel FM (2001) Isochorismate synthase is required to synthesize salicylic acid for plant defence. Nature 414:562-565

Wuest WM, Sattely ES, Walsh CT (2009) Three siderophores from one bacterial enzymatic assembly line. J Am Chem Soc 131: 5056-5057

Yang L, Rybtke MT, Jakobsen TM, Hentzer M, Bjarnsholt T, Givskov M, Tolker-Nielsen T (2009) Computer-aided identification of recognized drugs as Pseudomonas aeruginosa quorum-sensing inhibitors. Antimicrob Agents Chemother 53: 2432-2443

Yin MJ, Yamamoto Y, Gaynor RB (1998) The anti-inflammatory agents aspirin and salicylate inhibit the activity of IкB kinase$\beta$. Nature 396:77-80

Yuan ZC, Haudecoeur E, Faure D, Kerr KF, Nester EW (2008) Comparative transcriptome analysis of Agrobacterium tumefaciens in response to plant signal salicylic acid, indole-3-acetic acid and $\gamma$-amino butyric acid reveals signalling cross-talk and Agrobacterium-plant co-evolution. Cell Microbiol 10:2339-2354

Zhang S, Moyne AL, Reddy MS, Kloepper JW (2002) The role of salicylic acid in induced systemic resistance elicited by plant growth-promoting rhizobacteria against blue mold of tobacco. Biol Control 25:288-296 